\title{
Maciej Czerwiński
}

Uniwersytet Jagielloński

Kraków

\section{Europa jako znak w nowomowie jugosłowiańskich komunistów na przykładzie wystąpień Josipa Broza Tity}

Celem niniejszego artykułu jest próba rekonstrukcji treści znaku Europa w dyskursie komunistów jugosłowiańskich na przykładzie wystąpień przywódcy i dyktatora komunistycznej Jugosławii Josipa Broza Tity ${ }^{1}$. Analiza taka - zgodnie z założeniami modelu Romana Jakobsona i wszystkich innych modeli komunikacyjnych - uwzględnia wszelkie możliwe uwarunkowania kontekstowe i role interlokutorów, aby jak najwnikliwiej naświetlić dynamiczne przebiegi semiozy znaku Europa (w tym znaków pokrewnych) oraz jej konsekwencje dla preferowanej przez ideologię komunizmu jugosłowiańskiego wizji świata. Już na wstępie należy odnotować, że semioza taka - za sprawą czynników pozajęzykowych - będzie znacznie odbiegać od procesów analogicznych w innych krajach byłego bloku wschodniego.

1 Korzystam z 20-tomowego wydania przemówień i artykułów Tity z lat 1941-1965; zob. J. B. Tito, Govori i članci, Naprijed, Zagreb 1959-1965. Cytując, podaję wyłącznie numer tomu i stronę. 
Zgodnie z tradycją badań prowadzonych przez Michała Głowińskiego używam terminu nowomowa (wymiennie z terminami język i $d y s k u r s$ ), ponieważ analizowane teksty powstały w analogicznych okolicznościach politycznych: w totalitarnym państwie komunistycznym. Charakteryzują je także zjawiska typowe dla tego „stylu”, przede wszystkim wyraziste wskaźniki oceny, wszechobecne dychotomie, zrytualizowane formuły słowne ${ }^{2}$ itd. Odnotujmy jednak na marginesie, że nowsze badania nad dyskursem, zgłębiające mechanizmy oddziaływania władzy poprzez język w społeczeństwach demokratycznych, pokazały, iż wiele z tych mechanizmów stosuje się nie tylko w państwach o ustroju totalitarnym. Niewykluczone więc, że należałoby zrewidować znaczenie terminu nowomowa lub dookreślić go jako nowomowe totalitarna. Można również termin nowomowa zarezerwować dla reżimów totalitarnych, ale wówczas konieczne będzie przeformułowanie jego definicji ${ }^{3}$.

\section{1}

Powszechne w slawistyce - także bałkańskiej - zainteresowanie kategorią Europy w kulturach słowiańskich wynikało z potrzeby opisania dokonujących się zmian społeczno-politycznych, które zaszły na początku lat dziewięćdziesiątych XX wieku. Zjawiska przewartościowań systemów semantycznych - w języku i w literaturze, czyli ogólnie mówiąc: w kulturze - omawiano najczęściej w kategoriach zmiany. W odniesieniu do Słowian południowych zaobserwowano, udokumentowano i zweryfikowano kilka istotnych kwestii.

Stwierdzono przede wszystkim, że w kulturze chorwackiej - niezależnie od wyznawanego światopoglądu - ugruntował się mechanizm manifestowania europejskich źródeł kultury, co przełożyło się - mówiąc metajęzykiem - na nasycenie treści znaku Europa pozytywnymi konotacjami. Wpłynęło też na umieszczenie etnonimu Chorwaci i toponimu Chorwacja w tym samym polu semantycznym co pojęcia Europy (a ściślej: Europy Zachodniej). Oczywiście nie wszystkie opcje ideowe w ten sam sposób definiowały swój stosunek do starego kontynentu, gdyż ostatecznie - podobnie jak w Polsce - poróżnił je stosunek do Unii Europejskiej. Można zatem mówić o istnieniu wielu różnych koncep-

2 M. Głowiński, Nowomowa i ciagi dalsze, wyd. 2, Kraków 2009. Jerzy Bralczyk unika słowa nowomowa, natomiast posługuje się terminem język lub teksty propagandowe. Zob. tenże, O języku polskiej propagandy politycznej lat siedemdziesiątych, Warszawa 2001.

${ }^{3} \mathrm{Na}$ ten temat zob. M. Czerwiński, Nowomowa po jugosłowiańsku, „Studia z filologii polskiej i słowiańskiej”, 47, Warszawa 2012. 
cji Europy, a w ślad za tym - wielu Europ (nawiasem mówiąc, wyrażenie više Europa stało się ważnym elementem repertuaru retorycznego współczesnych ideologii prawicowych). Mówiąc zupełnie umownie: w dyskursach liberalnych i lewicowych UE jest konceptualizowana jako naturalny kontynuator Europy (synonimizacja), podczas gdy w dyskursach prawicowych instytucja ta jest ujmowana jako zaprzeczenie prawdziwej Europy (antonimizacja). Obie te opcje używały podobnego mechanizmu wykluczania wroga ideologicznego, ale to właśnie ta druga popadła w explicite wyrażany antyserbizm i antyjugoslawizm ${ }^{4}$. Tym samym najważniejszą cechą konotacyjną pojęcia Europa w tym kodzie stała się przynależność do świata Zachodu, a to z kolei doprowadziło do synonimizacji Europy z Europa Zachodniq oraz do świadomego i przemyślanego zabiegu wykluczania prawosławnych Serbów (ekskluzywne „oni”).

W kulturze serbskiej strukturyzacja tych pojęć miała oczywiście zupełnie inny charakter. Ideologia konserwatywna - skupiona szczególnie wokół Serbskiej Cerkwi Prawosławnej lub intelektualistów podkreślających rolę Cerkwi w życiu narodu - odwoływała się do tradycyjnego w kulturze prawosławnej antyokcydentalizmu. Doszło zatem do utożsamienia - podobnie jak w dyskursach chorwackich - Europy z Europa Zachodnia, ale, inaczej niż w Chorwacji, celem takiego zabiegu było wyeksponowanie negatywnej roli Kościoła katolickiego i Zachodu w ogólności. Skoro więc inna była motywacja utożsamienia obu pojęć, znak Evropa nasycił się w tym dyskursie konotacjami skrajnie negatywnymi. Co więcej, Europa Zachodnia - a także jej najbardziej wyraziści przedstawiciele (najbardziej typowe egzemplarze tego zbioru, czyli Niemcy, Wielka Brytania i oczywiście Watykan, a także - jako element Zachodu - Stany Zjednoczone) - zaczęła w tym kodzie ewokować postawy antyserbskie. Wszystkie kraje zachodnie oskarża się o świadome i cyniczne wywołanie wojny w byłej Jugosławii, której celem nadrzędnym miało być upokorzenie czy wręcz eksterminacja Serbów. Z kolei ideologia liberalna i lewicowa pojęciu Europy - podobnie zresztą jak wszystkie ideologie chorwackie - przypisała pozytywny znak wartości. Pociągnęło to za sobą inkluzję Serbów jako hiponimu w obręb kategorii hiperonimicznej - Evropy. Taka strategia nie miała na celu zakwestionowania przynależności Serbii do europejskiego Wschodu, lecz co najwyżej afirmację wyjątkowego, to jest pogranicznego

${ }^{4}$ W swoim wcześniejszym tekście zbyt pochopnie przypisałem takie zjawiska tylko ideologii konserwatywnej; M. Czerwiński, Chorwacja między Europa a Bałkanami. Analiza dyskursu prasowego, [w:] W poszukiwaniu nowego kanonu. Reinterpretacja tradycji kulturalnej w państwach postjugosłowiańskich po 1995 roku, red. M. Dąbrowska-Partyka, Kraków 2005, s. 97-116; zob. też: M. Dąbrowska-Partyka, Chorwacja w Europie - Europa w Chorwacji, [w:] tamże, s. 351-370. 
miejsca Serbów. Nie doprowadziło to również do desynonimizacji pary Europa-Europa Zachodnia, lecz wyeksponowało te cechy kultury serbskiej, które mają źródła zachodnioeuropejskie. Mówiąc metajęzykiem instrumentarium kognitywistycznego, doszło tu do przesunięcia treści peryferyjnych tego znaku do centrum.

Można zwięźle powiedzieć, że gdy w całej chorwackiej praktyce komunikacyjnej Europa (Zachodnia) zawsze stanowi centralny punkt odniesienia (różne opcje ideologiczne spierają się najwyżej o treść tego pojęcia), tak w serbskiej istnieje poważna rozbieżność co do aksjologii tego znaku. Jeszcze inną sprawą jest dyskutowana obecnie integracja z UE. Poszczególne ideologie - na potrzeby bieżącej retoryki politycznej - wykorzystują sprzeczności w obrębie pola semantycznego Europa - UE. Na przykład niektóre chorwackie kody narodowe eksponowały pozytywne wartościowanie Europy, ale negatywne $U E$, podkreślając - skądinąd słusznie - iż nie są to pojęcia synonimiczne ${ }^{5}$.

I jeszcze jedna uwaga natury formalnej. Otóż polskie słowo Europa ma w słowiańskich językach byłej Jugosławii dwa odpowiedniki, Europa i Evropa. Podczas gdy drugiego używa się w języku serbskim, pierwszy, choć niekonsekwentnie, występuje w języku chorwackim (w język Boszniaków preferuje się również formy chorwackie). Procesy kodyfikacji w latach dziewięćdziesiątych próbowały chorwackiej praktyce językowej narzucić słowo Europa jako wariant jedynie właściwy, bo łaciński, czyli zachodnioeuropejski. Taki zabieg nie doprowadził jednak ani do jego upowszechnienia, ani też do jego ideologizacji (wyrazu Evropa - na zmianę z „poprawnym” wariantem Europa - używali czasem tacy prawicowi politycy, jak Franjo Tuđman lub Nenad Ivanković).

\section{2}

Powyższe dość ogóle rozważania zdają sprawę z rzeczy fundamentalnej. Otóż słowo Europa/Evropa nie ma ani w kulturze chorwackiej, ani w serbskiej, ani w żadnej innej ujednoliconego znaczenia. Należy więc uznać, że nie możemy mówić - chyba że umownie i na płaszczyźnie pewnej konwencji - o istnieniu jedynego znaku Europa w języku chorwackim czy w języku serbskim. Możemy co najwyżej mówić o wa riantach tego słowa realizowanych w różnych kodach języka ogólnego. Znaki w takim ujęciu - zgodnie z koncepcją

${ }^{5}$ M. Czerwiński, Dyskurs antyunijny a kulturowa matryca Europy na podstawie wywiadu $z$ politykiem chorwackiej prawicy Nenadem Ivankoviciem, [w:] Polska i Chorwacja w Europie Środkowej, red. P. Żurek, Bielsko-Biała 2007, s. 593-607. 
Bachtina - są naznaczone kontekstami, w jakich się pojawiały. Każdy komunikat - za sprawą kontekstu - to wyławianie pewnych cech semantycznych $\mathrm{z}$ abstrakcyjnej przestrzeni treści danego znaku. Ponieważ takie wyławianie jest w istocie definiowaniem słowa, oznacza to, że każdy język przedmiotowy jest w jakimś stopniu metajęzykiem. Za każdym razem, mówiąc o rzeczach zewnętrznych wobec języka, definiujemy na własne potrzeby użyte przez nas znaki, i z tego właśnie powodu te same słowa nie są - na pewnym poziomie semantycznym - tymi samymi słowami. Abstrakcyjnie są one nośnikami wszystkich wiązanych z nimi treści, ale konkretnie ewokują odmienne, czasem zupełnie wykluczające się znaczenia. Oto nieuniknione, i polifoniczne w swojej istocie, brzemię języka ${ }^{6}$.

Z powyższego wynika, że każdy użytkownik kodu korzysta z systemowego repertuaru w sposób umiarkowanie dowolny. Dowolność tę specyficznie ograniczają „słowno-ideologiczne perspektywy”, czyli zakorzenienie nadawcy w konkretnych wizjach świata. Stąd Bachtinowskie języki - rozumiane tu jako „sprzeczne języki” w „różnojęzykowym gwarze” (czyli nieustannym dialogu) - to dyskursy czy kody. Tak więc każdy kod ma swój semantyczny (a ściślej: pragmatyczny) wariant słowa Europa. To właśnie kod afirmuje konceptualizację, która legła u podstaw semiozy, czyli decyduje o denotacjach (czym jest Europa?) i konotacjach (jakie cechy/wartości jej przypisujemy? co implikuje? itd.).

\section{3}

Jak już była mowa, kategorię Europy w dyskursie po roku 1990 analizowano jako z mianę - transformację z jednego stanu rzeczy w drugi, mówiąc operacyjnie: zmianę semantyczną. Problem jednak w tym, że nie wiemy, jaki był stan wyjściowy, z którego owa zmiana miałaby się dokonać. Poza intuicją nie dysponujemy bowiem badaniami tego pojęcia w językach i kulturach sprzed rozpadu Jugosławii. Używam formy mnogiej języki, aby podkreślić, że komunikacja językowa w komunistycznym państwie, nawet w sferze publicznej, nie była monolitem. Zdeklarowani komuniści - pozostańmy tylko przy nich - używali różnych wariantów ,języka komunistycznego”, należeli bowiem do

${ }^{6}$ O koncepcji semiotycznych badań dyskursu pisałem w artykule Życie znaków w sieci kodów - czyli o semiotycznie zorientowanych badaniach dyskursu i stylu (na przykładzie znaku „naród chorwacki”), „Slavia Meridionalis” 2010, t. 10, Warszawa, s. 35-52; zob. też: M. Bachtin, Problemy literatury i estetyki, tłum. W. Grajewski, Warszawa 1982, s. 117. 
różnych frakcji, mieli różne pochodzenie, różnie definiowali się w kategoriach przynależności narodowej czy wreszcie funkcjonowali w różnych momentach historycznych itd. Mówiąc operacyjnie, posługiwali się różnymi kodami ideologicznymi, choć wszystkie one - mniej lub bardziej wyraźnie - były aktualizacjami kodu komunistycznego. Można więc powiedzieć, że każdy dyskurs uznany za komunistyczny będzie mniej lub bardziej wyraźnie - a więc w jakimś stopniu - realizował dyspozycje kodu komunistycznego. $\mathrm{Z}$ tego wyłania się z kolei problem metodologiczny: jak stworzyć reprezentacyjną bazę tekstów, które mogłyby się stać materiałem badawczym. Jest to, wydaje się, problem nierozstrzygalny i zawsze subiektywny (subiektywne jest bowiem zawsze pytanie, czy wybrać teksty Tity czy Đilasa, a jeśli Tity, to z lat pięćdziesiątych czy z 1971 roku, a może teksty KC KPJ lub KC SKH, czy też autoryzowane podręczniki do nauki historii itd.).

Proponowany tu wybór wszystkich zebranych tekstów Josipa Broza Tity nie pretenduje do uniwersalnego, choć - jak wiadomo - to właśnie jugosłowiański przywódca był najbardziej prominentną postacią ruchu komunistycznego i spiritus movens wszelkich korekt ideologii socjalistycznej, w tym jej języka.

\section{4}

Analiza materiałów badawczych wyraźnie wskazuje, że pojęcie Europy - rozumiane w kategoriach cywilizacyjnych (a w takiej postaci najczęściej występowało po rozpadzie Jugosławii) - jest w dyskursie Tity niemal zupełnie nieobecne. W latach dziewięćdziesiątych, przypomnijmy na przykład prezydenta niepodległej Chorwacji Franja Tuđmana, skądinąd byłego generała wojsk Tity, wcześniej gorliwego komunisty, Europa jako hasło wywoławcze cywilizacji łacińskiego Zachodu (do którego Chorwacja miała naturalnie należeć) było jednym z kluczowych centrów semantycznych jego dyskursu. 28 kwietnia 1995 roku rządowy i lojalny wobec władzy dziennik „Vjesnik” donosił: „Predsjednik Tuđman pozvao da se osujete svi pokušaji destabilizacije Hrvatske, jer bi se njima išlo na ruku onima koji Hrvatsku žele vratiti u neku jugoslavensku ili balkansku federaciju”. Z kolei 3 sierpnia 1996 roku, po dwudniowej wizycie w USA, Tuđman zakomunikował opinii publicznej w telewizji państwowej HRT: „Dobili smo podršku od Sjedinjenih Država koje potvrđuju da Hrvatska pripada Srednjoj Europi, a ne Balkanu”. Choć oba zdania pojawiają się w kontekście politycznym, ich znaczenie wykracza daleko poza ten obszar, stanowiąc centralne hasło kształtujące preferowaną wizję ideologiczną: Chorwacji w świecie wartości zachodnioeuropejskich. 
W przeciwieństwie do takiej strategii, w dyskursie Tity (również, przypomnijmy, Chorwata) dominują dwie inne płaszczyzny semantyczne słowa Europa: geograficzna i ekonomiczna. W pierwszym przypadku Europa jest kontynentem, nie zaś systemem wartości ${ }^{7}$, podczas gdy w drugim - stanowi istotny punkt odniesienia w ocenie poziomu zamożności państw. Taka konceptualizacja starego kontynentu spowoduje, że w dyskursie komunistów nad Europa przeważać będzie pojęcie pokrewne - Zachód (i oczywiście jego antonim Wschód), co z kolei stanie się wygodnym narzędziem kształtowania komunistycznego wariantu zimnowojennej wizji świata.

Brak wyraźnego nacechowania pojęcia Europy konotacjami o przynależności cywilizacyjnej do świata Zachodu jest zapewne świadomym zabiegiem, który nie ma na celu uwypuklania wartości utożsamianych z europejskimi. Odwołanie się do tych wartości oznaczałoby bowiem konieczność afirmacji niektórych fundamentów aksjologicznych ancien regime’u oraz systemów wartości, które w rewolucji proletariackiej ulegają daleko posuniętej krytyce (społeczeństwa stanowego, instytucji Kościoła, feudalizmu itd.). Co ciekawe, badany język - nie jest to zresztą wyłącznie osobliwością jugosłowiańską - ponad przeciętną używa terminów denotujących wartości, które niewątpliwie wywodzą się z cywilizacji Europy Zachodniej, choć niekiedy pochodzą z innych tradycji i odmiennych postaw światopoglądowych (demokracija, ravnopravnost, sloboda, humanizam, koegzistencija itd.). Tak więc w komunistycznej nowomowie dochodzi do próby uwolnienia tych pojęć z konotacji, jakie wyznacza im pole znaku Europa. To z kolei wpływa na ich upodmiotowienie, które w dalszej kolejności umożliwi przedstawienie ich jako wartości autentycznie komunistycznych, nie zaś pochodzących z jakiegokolwiek innego porządku.

Ujmowanie Europy jako pojęcia geograficznego otwiera pytanie, gdzie konkretnie znajduje się - w rzeczywistości 'pozajęzykowej' - desygnat słowa Europa i w odniesieniu do kogo/czego należy go odnosićs. Jeśli chodzi

7 Owa „czysta” geograficzność nie jest oczywiście pozbawiona potencjału aksjologicznego, ale jest on w tym kontekście zminimalizowany. W proponowanym tutaj ujęciu, i zgodnie $\mathrm{z}$ aksjomatami wielu nowszych metodologii lingwistycznych, żaden znak - w tym również nazwa własna - nie jest pozbawiony znaczeń konotacyjnych. Każde słowo, w kontekście czy poza kontekstem, jest znaczące (co więcej, znaczący jest również brak jakiegoś słowa). I tak słowo Europa generuje wiele konotacji aksjologicznych, np. stary kontynent, stara cywilizacja, bogactwo itd. Może też generować konotacje zależne od światopoglądu interlokutora, np. humanizm vs. imperializm. Mówiąc więc, że potencjał aksjologiczny jest zminimalizowany, mam na myśli tyle, że ten konkretny kontekst ich nie uwypukla.

${ }^{8}$ Odnotujmy tutaj, że desygnatów nie rozpatruję w kategoriach czysto ekstensjonalnych (czyli jako bytów zewnętrznych), lecz - zgodnie z propozycją Umberta Eco - intensjonalnych. 
o usytuowanie komunistycznej Jugosławii w takiej czy innej przestrzeni geograficznej, to należy zauważyć, że w historii istnienia tego państwa pojawiły się trzy momenty, które znacząco zmieniały konceptualizację dychotomii pojęć geopolitycznych (a odnotujmy, że - jak wskazywał Michał Głowiński - dychotomiczne konstrukcje wartościujące są w komunistycznej nowomowie najbardziej wyrazistym mechanizmem językowym ${ }^{9}$ ).

W pierwszym okresie - trwającym do roku 1945, czyli do końca II wojny światowej - Jugosławię ujmuje się w szerszym kontekście sojuszników koalicji antyhitlerowskiej. W okresie drugim - od 1945 do 1948 roku - Jugosławia zostaje usytuowana w granicach świata bipolarnego, podzielonego na Zachód (kapitalistów) i Wschód (kraje komunistyczne). Ostateczna zmiana dokonuje się w roku 1948, czyli w momencie zerwania braterskiej wspólnoty ze Związkiem Sowieckim, co wymusza korektę wcześniejszych konceptualizacji. Jugosławia staje się bytem pomięd zy oboma blokami państw, ale do pełnej afirmacji takiego paradygmatu dojdzie dopiero w połowie lat pięćdziesiątych, gdy zacznie się ostatecznie kształtować nowa siła światowej polityki - ruch niezaangażowanych (pokret nesvrstanih, neangažirani/neangažovani). Takie przeformułowanie pojęć doprowadzi do poważnych konsekwencji w obrębie całego dyskursu komunistów jugosłowiańskich.

Ażeby zobrazować skalę zmiany konceptualizacji i tym samym korekty w ocenie uniwersum zachodniego i wschodniego oraz miejsca Jugosławii w świecie, przytoczmy ostatnie fragmenty przemówienia Tity w Belgradzie z roku 1945 (Pozdravna riječ na antifašističkoj skupštini Srbije z 10 listopada 1944 roku). Czytamy tam:

Neka živi velika Demokratska Federativna Jugoslavija!

Da žive naši veliki saveznici Sovjetski Savez, Engleska i Amerika!

Da živi naša saveznica Francuska i ostali naši saveznici!

Smrt fašizmu - sloboda narodu! (I, 250).

W tej zrytualizowanej formule, zamykającej wszystkie przemówienia w okresie wojny, Anglia i Francja (także Ameryka) reprezentują Zachód. Usytuowanie ich

Stanowią one uniwersum znaczenia, a więc uniwersum kultury. Wyrażenie rzeczywistość pozajęzykowa jest więc konwencjonalne, a kryje się w nim rzeczywistość znaczenia, a nie rzeczywistość przedmiotu jako takiego. Zob.: U. Eco, Teoria semiotyki, tłum. M. Czerwiński, wyd. 2, Kraków 2009.

9 Zob. M. Głowiński, Nowomowa..., s. 12-14. Uściślijmy, że mechanizm ów wykorzystywany jest nie tylko w nowomowie, ale w każdym dyskursie, choć oczywiście stopień jego radykalizacji zależeć będzie od natężenia tendencji totalitarnych. Im ideologia bardziej totalitarna (lub dążąca do totalitarnej organizacji społecznej), tym jednowartościowe polaryzacje aksjologiczne będą częstsze. 
wraz ze Związkiem Sowieckim w jednym porządku semantyczno-aksjologicznym musi z perspektywy późniejszych dyskursów wywoływać zaskoczenie, ale w tym konkretnym kontekście jest zupełnie uzasadnione, gdyż Anglia i Francja to sojusznicy. W tej samej odezwie jugosłowiański przywódca mówi rzecz następującą:

I mi, mali narodi u moru fašističke Evrope, digli smo se da spasemo čast svojih naroda, da se borimo za svoju nezavisnost i da jednoga dana smjelo i otvorenih očiju možemo kazati: mi smo dali sve što smo mogli da bismo doprinijeli opštoj stvari, to je o slobađanju Evrope, oslobađanju naše zemlje od fašističkog okupatorskog iga (I, 250).

Jak więc widać, obowiązuje tutaj wyrazisty podział na „nich” - Europę faszystowskq i na "nas” (czyli także wspomnianych wyżej sojuszników), którzy wspólnie - wbrew różnicom ideologicznym (tutaj świadomie przemilczanym) - występują przeciwko niesprawiedliwości i wyzwalają Europę. Europa jawi się więc jako wspólne dobro - i Wschodu, i Zachodu. Istotnym elementem tego dyskursu i semiozy znaku Europa jest także uwypuklenie faktu, że ostatnia wojna stanowi w historii pierwszy taki przypadek, kiedy narody południowosłowiańskie, związane braterst wem i jed nością, stają się podmiotem, a nie tylko przedmiotem polityki międzynarodowej:

Nećemo više da budemo dječja lopta ili moneta za potkusurivanje! Mi smo u ovoj borbi stekli pravo da ravnopravno sa saveznicima učestvujemo i u ovom ratu i u izgradnji nove i srećnije Evrope, ne samo Jugoslavije! (I, 248).

W sensie semiotycznym mamy tutaj do czynienia z próbą zakwestionowania dotychczasowego rozczłonkowania kontinuum w oglądzie polityki międzynarodowej, w której agensami były dotychczas - jak twierdzi Tito - wyłącznie wielkie potęgi. Na kontinuum to próbuje się narzucić zupełnie nową konceptualizację, w której Jugosławia - jako relewantna jednostka semantyczna (do tej pory marginalizowana) - ma odgrywać równie istotną rolę jak inne państwa. Dochodzi zatem do zmodyfikowania segmentacji tego kontinuum, co - jak się przekonamy - będzie miało w późniejszym okresie poważne konsekwencje.

W tej chwili jednak istotne jest to, że od wyzwolenia ${ }^{10}$ (maj 1945 roku) $\mathrm{w}$ analizowanych tekstach sojusznicy zachodni przestają się już pojawiać, a jedynym zwycięzcą wojny są wyłącznie kraje komunistyczne. Takie natychmiastowe przeobrażenie możemy wiązać ze zmianą polityki porozumienia na politykę konfrontacji, a w ślad za tym - kształtowania porządku zimno-

${ }^{10}$ Odnotujmy, że słowo wyzwolenie stanowiło centrum semantyczne w języku komunistów. Jednakże w dyskursach antykomunistycznych po rozpadzie Jugosławii zaczęto to pojęcie relatywizować: zamiast dotychczasowego wyzwolenia pojawiło się tako zvano oslobođenje (lub oslobođenje w cudzysłowie), co miało na celu zakwestionować jego autentyczność. 
wojennego, który pojawił się zapewne pod naporem dyrektyw z Kominternu lub bezpośrednio z Komunistycznej Partii Związku Sowieckiego. Z biegiem czasu byli sojusznicy staną się - jako kapitaliści, imperialiści, reakcja, obszarnicy czy kolonialiści - głównym wrogiem rewolucji ludowej.

W tak zdefiniowanej rzeczywistości nie ma oczywiście miejsca na eksponowanie różnic między Europą a Bałkanami. Jedynym wyjątkiem, który mógłby sugerować tendencję odwrotną (ale w istocie potwierdza regułę), jest fragment, gdzie Tito przeciwstawia sobie oba te pojęcia. Nie czyni jednak tego po to, by jugosłowiańskie narody poróżnić, lecz by im implicite narzucić ideę jedności. „Mi se - czytamy - nalazimo na velikoj historijskoj prekretnici ujedinjavanja Slovena na Balkanu. [...] Dosta su se u toku historije hrvatski sinovi bili na svim poljima Evrope za tuđe interese" (I, 294). Jest to apel do Chorwatów (odezwa wygłoszona została w odbitym z rąk usztaszy Zagrzebiu 21 maja 1945 roku), ale Bałkany w zamierzeniu autora wyzwalają tutaj konotacyjną cechę swojskości, podczas gdy Europa ewokuje obcość. W ten przebiegły sposób narzuca się chorwackim interlokutorom przekonanie o ich narodowej i cywilizacyjnej odrębności (jakże istotnej w tożsamości Chorwatów), jednocześnie zaś sytuuje ich się na Bałkanach, wraz z Serbami i pozostałymi narodami południowosłowiańskimi. W takim kontekście Europa zostaje niemal automatycznie opatrzona negatywnymi konotacjami, z kolei Bałkanom - odwrotnie - nie przypisuje się cech ani negatywnych, ani nadmiernie pozytywnych. Celem takiej pozorowanej neutralności jest zapewne osłabienie potencjału negatywnej aksjologii zawartej w chorwackim wariancie znaku Bałkany, o czym możemy się też przekonać w następującym fragmencie: „To je bila misao da bez bratstva i jedinstva nema sreće među narodima Jugoslavije, nema sreće na cijelom Balkanskom poluostrvu" (I, 292). Jeśli przypomnimy sobie obsesję, jaką wobec Bałkanów miał chorwacki prezydent Franjo Tuđman, uświadomimy sobie, jak wielka zmiana w semantyce tych pojęć dokonała się na przestrzeni zaledwie kilkudziesiąciu lat.

Pojęcie Europy ustanawia również gniazdo semantyczne dla denotacji płaszczyzny ekonomicznej, dzięki której możliwe staje się stworzenie i petryfikowanie w dyskursie podziału na kraje rozwinięte i nierozwinięte (zacofane). Na tej płaszczyźnie Europa (czytaj: Europa Zachodnia) nabiera pozytywnych konotacji, gdyż jawi się jako emblemat dobrobytu, a więc cel, do którego należy dążyć: „Sve više se udaljavamo od nivoa nerazvijenih zemalja i približavamo nivou razvijenih zemalja Evrope"11 (XV, 175). Z wyrażeniem tej tezy - choć

11 Podobne przekonanie zakodowane jest we fragmencie, w którym mówi się o przepaści „,između nedovoljno razvijenih zemalja i visoko razvijenih područja svijeta, kao što su Evropa i Sjeverna Amerika” (t. 16, s. 19; zob. też: t. 16, s. 105, 118). 
niejawnie - mamy również do czynienia we fragmencie, gdzie czytamy, że „Beograd može da bude jedan od najljepših gradova u Evropi” (XV, 328). Powtórzmy raz jeszcze: Europa to ekonomiczny, a nie cywilizacyjny punkt odniesienia. W ostatecznym jednak rozrachunku bogactwo starego kontynentu stanie się w tym dyskursie przyczyną wystawienia mu ogólnie negatywnej oceny.

Zanim wyjaśnimy ten problem, trzeba odnotować, że Europa jest w tym kontekście znakiem bardziej szczegółowym - hiponimem, a znakiem nadrzędnym - hiperonimem jest znak o szerszej denotacji, czyli Zachód. Tak jak w dyskursach współczesnych Europie przeciwstawiano Bałkany, tak w analizowanych tu tekstach Zachodowi (krajom kapitalistycznym) przeciwstawia się Wschód (kraje komunistyczne). Oczywiście ów paradygmat ulega po roku 1948 doprecyzowaniu: podczas gdy wcześniej Jugosławia stanowiła element świata Wschodu (semantyczna relacja inkluzyjności), tak po zerwaniu Tity ze Stalinem w 1948 roku staje się niezależna zarówno od Wschodu, jak i Zachodu (upodmiotowienie). Prowadzi to do zakwestionowania przeświadczenia o bipolarnym podziale świata (a tym samym do przekształcenia dychotomicznej relacji my - oni) i do wyeksponowania trzeciego podmio tu w relacjach międzynarodowych. Można chyba zaryzykować tezę, że sukces retoryki komunistów jugosłowiańskich - także w skali międzynarodowej - polegał na narzuceniu sztywnemu i zakorzenionemu paradygmatowi binarnemu Wschód - Zachód nowej konceptualizacji i nowej propozycji rozczłonkowania kontinuum możliwych postaw w świecie powojennym. Zamiast dwóch jednostek semantycznych pojawiają się trzy, co wpływa na wyraźną zmianę relacji semicznych. Bez względu na wszelkie słuszne krytyki pod adresem jugosłowiańskich komunistów i samego Tity (choćby za represje kończące się dla wielu obywateli śmiercią, za reglamentowanie wolności obywatelskich itd.) nie można im odmówić umiejętności propagandowych, dzięki którym z niezamożnej Jugosławii udało im się uczynić kraj ważny, bo patronujący całej rzeszy państw poszkodowanych w rezultacie niesprawiedliwego kolonializmu.

Omówione wyżej dwie płaszczyzny semantyczne, geograficzna i ekonomiczna, oraz okoliczności polityczne z lat pięćdziesiątych wpływają ostatecznie na ukonstytuowanie się pojęcia Jugosławia jako podmiotu egzogenicznego, to jest zewnętrznego zarówno względem Zachodu (w tym Europy), jak i Wschodu. W dyskursie Tity Jugosławia - zwłaszcza od połowy lat pięćdziesiątych, gdy powstał ruch państw niezaangażowanych - występuje jako przedstawiciel kontynentu europejskiego, ale nie w odniesieniu do Bałkanów, lecz w odniesieniu do innych kontynentów: Azji, Afryki i Ameryki Łacińskiej.

Od tego momentu oba bloki, wschodni i zachodni, są określane zbiorczym znakiem wielkie potęgi (velike sile), który ma wyraźnie negatywne konotacje 
(zob. np. XIV, 60). Po spotkaniu przywódców ZSRS Nikity Chruszczowa i USA Dwighta Eisenhowera we wrześniu 1950 roku Tito nie pozostawia swoim odbiorcom złudzeń: porozumienie jest połowiczne, a więc wciąż pozostaje do przezwyciężenia „jaz koji razdvaja zapadne i istočne zemlje, to jest velike sile SSSR i SAD” (XVI, 131). Utrzymywanie takiej strategii, to jest synonimizacji Wschodu i Zachodu pod postacią ujednoliconej figury zbiorczej, stanie się konsekwentnym modus operandi dyskursu komunistów jugosłowiańskich. Dzięki temu ukształtuje się nowa dychotomia semantyczna: „oni” (wielkie potęgi: Zachód i Wschód) - „my” (małe narody, obrońcy uciśnionych). Konceptualizacja „nas” jest oczywiście opatrzona pozytywnym znakiem wartości, więc narody niezaangażowane przedstawia się jako antidotum na krzywdzacy i zagrażający pokojowi układ zimnowojenny, o czym świadczą choćby następujące fragmenty: „Te zemlje, među kojim se nalaze i Indonezija i Jugoslavija, igraju značajnu ulogu u borbi za sprečavanje agresije i drugih negativnih poduhvata i za popuštanje međunarodne zategnutosti” (XIV, 34) oraz „Da, mi nemamo atomske bombe! Ali mi imamo moral, mi imamo moralne snage, mi predstavljamo ogroman dio čovječanstva" (XVII, 138).

Widzimy więc, że w omawianych okolicznościach politycznych ani pojęcie Europy, ani pojęcie Zachodu nie jest najistotniejsze w kształtowaniu dychotomicznego obrazu rzeczywistości. Treści obu tych znaków ulegają zatem daleko posuniętej modyfikacji. Co więcej, rezygnacja z przynależności do któregokolwiek z bloków w zimnowojennej rzeczywistości niemal automatycznie predestynuje Jugosławię do odgrywania istotnej roli międzynarodowej, co staje się atutem w afirmacji własnej podmiotowości: „[...] naša se gledišta često više ne slažu sa Istokom nego sa Zapadom, ipak nas Istok kritikuje više nego Zapad. Baš zato vodimo nezavisnu politiku" (XIV, 348).

Pozytywną kategorię „my” nie definiuje więc cecha bycia krajem socjalistycznym (jak do 1948 roku) ani też krajem eu ropejskim (jak w Chorwacji po 1990 roku). Definiuje ją cecha bycia krajem nieza angażowa nym, to jest dalekowzrocznym i kierującym się autentycznymi wartościami humanistycznymi (wolnością, pokojem, równouprawnieniem i sprawiedliwością). Co zatem istotne, w nowo powstałym sojuszu krajów Trzeciego Świata e u ro pejskość staje się swojego rodzaju zobowiązaniem:

Narodi Jugoslavije žive u Evropi, ali su oni duboko svijesni da ne mogu biti sigurni za svoj miran razvitak i život ako u drugim dijelovima svijeta ne bude vladao mir i ako drugi narodi, kao na primjer afrički, ne budu slobodni i nezavisni (XVI, 248),

a jednocześnie brzemieniem, wobec którego należy zająć jedyną słuszną postawę: 
Ti narodi znaju da mi ne spadamo među one koji prema njima imaju takve namjere. Oni znaju da je naše mjesto u Evropi i u svijetu dostojno naših naroda, oni znaju da mi nesebično doprinosimo stvari mira i stvari oslobođenja kolonijalnih naroda od njihove potčinjenosti drugima (XIV, 165).

Tito w innym miejscu stosuje przebiegły zabieg zawłaszczenia konceptualizacji pochodzącej z dyskursów egzogenicznych, czyli nieeuropocentrycznych i niepowstałych w Europie, lecz w krajach Trzeciego Świata ${ }^{12}$. W takiej optyce symbolem Zachodu i Europy (te znaki stają się w tym porządku niemal synonimiczne) okazuje się biały człowiek - uosabiający zamożnego ciemiężyciela i bezwzględnego oprawcę. Oczywiście, przedstawiciele Jugosławii, choć również reprezentują rasę białych ludzi (ljudi iz Evrope, bijeli ljudi), są tutaj kategorią odrębną, ponieważ „dolaze sa najboljim namjerama prema njima, [oni su] njihovi prijatelji” (XVI, 344).

Dzięki takiej strategii udaje się Jugosławię przedstawić jako jedyny kraj w Europie, który ma zrozumienie dla ruchów wyzwoleńczych i dekolonizacyjnych w krajach najbiedniejszych: „Oni [narody Trzeciego Świata] nam ne jedanput kazali da je Jugoslavija jedina zemlja u Evropi o koju oni imaju povjerenja" (XIV, 167).

Ważnym gniazdem semantycznym dla tego dyskursu jest także dalsze uszczegółowienie pojęcia wielkie potęgi: występują one również jako potęgi kolonialne (kolonijalne sile), które identyfikuje się przede wszystkim z Zachodem, nie ze Wschodem (Wschód - pomimo nieporozumień politycznych - wyznaje jednak te same, socjalistyczne wartości). Stąd pojawia się wyrażenie desygnujące świat Zachodu: ratoborne krugove na Zapadu, które „se prilično neodgovorno igraju sudbinom čitavog svijeta” (XV, 293). W innym kontekście czytamy: „Mi znamo da ima dosta ljudi u svijetu koji ne vole našu zemlju. Mnogi reakcionari na Zapadu otvoreno govore da ne vole našu zemlju. Štoviše, mnogi je i mrze, ali mi to razumijemo, jer oni, gledajući na našu zemlju polaze od svojih ličnih i klasnih interesa" (XVII, 39). Co więcej, Zachód - zgodnie z powszechnie panującymi przekonaniami - nigdy nie pozostaje wierny swoim wartościom, i właśnie to prowadzi go w pułapkę koniunkturalizmu i oportunizmu. Gdy Tito mówi, że „neki partneri sa Zapada ne mogu da se pomire sa činjenicom da se mi nećemo odricati naših principa radi trenutnih koristi” (XVI, 143), lub gdy twierdzi: „Ja ću na drugom mjestu govoriti o tome šta je omogućilo Hitleru i Mussoliniju tako lake pobjede u Evropi, ali

12 Zapewne wnikliwe studia tego problemu mogłyby zdemaskować ukryty w dyskursie Tity „orientalizm”, czyli mniej lub bardziej zgrabnie zawoalowane stereotypowe myślenie na temat Orientu, jak w studium Edwarda Saida; zob. tenże, Orientalism, New York 1979. Podobnie też dogłębna analiza reportaży autorstwa Ryszarda Kapuścińskiego - zadeklarowanego antykolonialisty - doprowadziła Johna Ryle’a do podobnych wniosków na temat polskiego pisarza; zob. tenże, Tropical baroque, African reality and the work of Ryszard Kapuściński, “Times Literary Supplement”, 27 July 2001, London. 
moram i ovdje da pomenem da su one došle kao rezultat čitave pretratne politike izvjesnih zapadnih sila - kao rezultat Minchena i drugog" (XVII, 11), to ewokuje tym samym negatywne konotacje zawarte w znaku Zapad. Zachód, czyli najczęściej Europa Zachodnia, jest w analizowanych tekstach nasycony negatywnym znakiem wartości jako gracz cyniczny. Odnotujmy na marginesie, że wszyscy późniejsi postjugosłowiańscy przywódcy, w tym Tuđman i Milošević, często sięgali po ten sam mechanizm. Tuđman w momencie, gdy Zachód (wówczas już jako wspólnota międzynarodowa) nie chciał uznać samodzielnych akcji wojskowych Chorwacji, Milošević - w trakcie bombardowań Jugosławii przez NATO.

Wróćmy jednak do problemu Zachodu. Wygodną strategią jego oczerniania jest wykorzystanie zabiegu metonimii: ,jeden kraj zachodni za cały Zachód”. Do najbardziej wyrazistych hiponimów Europy/Zachodu należy Francja. Państwo to staje się w dyskursie komunistycznym, jako kraj kapitalistyczny i kolonialny, reprezentantem charakterystycznej dla Zachodu polityki - po lityki bezwzględnej kolonizacji. Przed zgromadzeniem generalnym ONZ w roku 1960 Tito wypowiedział następujące zdanie:

Narod Alžira - koji i dalje podnosi teške žrtve za zadobijanje svoje slobode, čime zadužuje narode koji se bore za mir, nezavisnost i ravnopravnost - traži prirodna i zakonita prava za samoopredjeljenje. Ta prava mu je prošle godine i Francuska u načelu priznala, ali su pregovori koji su usljedili pokazali, na žalost, da francuska strana nije izvukla one praktične zaključke koji proizlaze iz priznanja prava na samoopredjeljenje... (XVI, 17-18).

Jeśli przypomnimy sobie wystąpienia Tity sprzed dnia wyzwolenia (9 maja 1945 roku), w których Francja była sojusznikiem koalicji antyhitlerowskiej, wówczas zdamy sobie sprawę, jak bardzo dyskurs komunistyczny - na potrzeby bieżącej polityki - modyfikował strukturę pola semantycznego wyznaczanego przez pojęcie Europa.

\section{5}

W artykule niniejszym przedstawiłem rekonstrukcję semiozy znaku Europa w dyskursie Josipa Broza Tity. Jak się okazało, jest ona uwikłana w wiele uwarunkowań kontekstowych, wynikających zarówno z okoliczności politycznych, jak i historycznych. Znak ów odgrywał istotną rolę w kształtowaniu jugosłowiańskiej optyki zimnowojennej. Jak już była mowa, bez względu na wszelkie słuszne krytyki pod ich adresem (choćby za represje czy reglamentowanie wolności obywatelskich) nie można im odmówić umiejętności propagandowych, dzięki którym udało się uczynić z niezamożnej Jugosławii kraj ważny w skali międzynarodowej. Warto też pamiętać, że Tito jest $\mathrm{z}$ dzisiejszej perspektywy postacią 
niejednoznaczną, a cenią go również najzacieklejsi krytycy systemu, na przykład cytowany już wcześniej Franjo Tuđman, który w swoim czasie powiedział:

Tito je bez dvojbe bio jedan od najvećih državnika Evrope razdoblja drugoga svjetskog rata. Bio je komunista, marksist, ali bio (je) veoma pragmatičan političar, i želio je ostvariti ravnopravnost hrvatskog naroda u Jugoslaviji, a razdijelio je isto tako da ta njegova socijalistička Jugoslavija bude ravnopravna u odnosu na Sovjetski savez odnosno na Staljina. Zasluge Tita su, što se hrvatskog naroda tiče, u tome što jo on... znači... s antifa šistič kim pokretom doveo hrvatski narod na stranu pobjedničkih i demokratskih sila antifašističke koalicije, što je omogućilo da se stvori federalna država hrvatska. [...] Zasluge u međunarodnoj politici su u tome da je ... znači, kao što sam rekao, pružio otpor, takav otpor Staljinu kad su zapadne sile bile gotovo bespomoćne u odnosu na taj jak komunistički blok, sovjetski blok, a i u odnosu na širenje komunizma u čitavome svijetu (wywiad z filmu Tuđ̆man ${ }^{13}$ ).

Ów fragment świadczy nie tylko o ambiwalentnym stosunku do Tity po rozpadzie Jugosławii ${ }^{14}$, ale przede wszystkim o tym, że język tamtych czasów nie umarł wraz ze śmiercią systemu i jego dyktatora. Wszystkie podkreślone wyrażenia noszą brzemię dawnych użyć, a także afirmują wartości, które Tito sam sobie i jugosłowiańskiemu komunizmowi przypisywał. Co więcej, wyrażenia te, jak dowodzi powyżej przeprowadzona analiza, pochodzą z repertuaru komunistycznej nowomowy.

Nie jest to zresztą sytuacja odosobniona. Wiele znaków, często nawet nadużywanych we współczesnej praktyce językowej w krajach byłej Jugosławii, częściej niż w Polsce, nosi „zapachy” języka komunistów. Dotyczy to głównie komunikacji politycznej, ale również niektórych terminologizmów, w tym na przykład językoznawczych (terminy baza [baza] i nadbudowa [nadgradnja] są powszechnie używane w refleksji nad problematyką języka standardowego). Zbadanie tego fenomenu jest istotne, gdyż umożliwi wniknięcie w linię rozwojową znaczeń językowych, a także zda sprawę z nieuświadamianej przez interlokutorów śladowej obecności nowomowy w ich współczesnym języku.

13 Film Jakova Sedlara (2008).

14 Problem recepcji Tity jest zupełnie inną kwestią, a symptomatycznym jej uosobieniem jest dyskusja na temat nazewnictwa ulic i placów. W Serbii na przykład zamieniono wszystkie nazwy ulic noszące jego imię, w Chorwacji wciąż trwa dyskusja na ten temat; zob. M. Czerwiński, Postkomunizm jako syndrom - słowa, figury, sensy. Chorwacja i Polska, [w:] Kultury słowiańskie między postkomunizmem a postmodernizmem, red. M. Dąbrowska-Partyka, Kraków 2009, s. 169-186. Do tej pory w większości miast Tito jest patronem i ulic, i placów (w Zagrzebiu - nawet jednego z najważniejszych - Trg Maršala Tita). Ostatnio część chorwackich elit - niekoniecznie prawicowych, jak np. Ivo Banac - wszczęła dyskusję na temat konieczności rozliczenia (zbrodni) okresu komunistycznego. Dyskusje te mają również na celu pozbawienie ulic i placów patrona, jakim był jugosłowiański dyktator. 
Wydaje się, że wynika to z tego prostego faktu, iż ogniwem pośrednim łączącym demokrację ludową z demokracją parlamentarną były ruchy narodowe, które w latach siedemdziesiątych rozwijały się niemal wyłącznie w ramach reżimu partyjnego, a nie poza nim. Doprowadziło to do modyfikacji nowomowy komunistycznej na potrzeby afirmacji nowych światopoglądów. Ów nowy język (na przykład język tzw. liberałów serbskich czy przedstawicieli chorwackiej wiosny wraz ze słynną Deklaracją o nazwie i statusie języka chorwackiego) był, posługując się tą retoryką, socjalistyczny $w$ formie, a narodowy $w$ treści ${ }^{15}$. Były więc owe ruchy - podobnie jak ich język - pomostem łączącym jugosłowiański komunizm z niepodległymi państwami i ich nowymi/starymi, to jest hybrydycznymi w swojej istocie językami.

\section{Europe as a sign in the Yugoslav Communist newspeak basing on the Tito's addresses}

\section{Summary}

Although the Yugoslav Communist newspeak resembled the Polish one on the formal level, it significantly different conceptualized and evaluated the extra-linguistic reality, including primarily notions referring to main subjects of the international politics. It resulted from a diverse place the Communist Yugoslavia had in the Cold War order and its role within the non-allied countries. As a result semantic relations were different in this discourse. The aim of this article is a reconstruction of the content of one of the most important signs in this language - the sign of Europe basing on the Yugoslav dictator's (Josip Broz Tito) addresses. The research demonstrates that the cultural and social-political context imposed other connotative features on the notion of Europe. As the result it has completely different functions that its Polish equivalent. This in turn leads to different types semiosis of this sign in both cultures and other signs coming from the same semantic field.

Key words: semiotics of culture, language Communists of Yugoslavia, Josip Broz Tito language, Europe.

Słowa kluczowe: semiotyka kultury, język komunistów Jugosławii, język Josipa Broza Tity, Europa.

${ }^{15} \mathrm{Na}$ ten temat zob. M. Czerwiński, Socjalistyczny $w$ formie, narodowy w treści. Chorwacka odmiana komunistycznej nowomowy w czasie tzw. chorwackiej wiosny, „Stylistyka”, XXI, Opole 2012. 